\title{
Early Guaraní Printing: Nieremberg's De la diferencia and the Global Dissemination of Seventeenth-Century Spanish Asceticism
}

\author{
D. Scott Hendrickson, S.J. \\ Loyola University Chicago \\ dhendrickson@luc.edu
}

\begin{abstract}
This article examines both how and why the Spanish Jesuit Juan Eusebio Nieremberg's (1595-1658) once famous treatise De la diferencia entre lo temporal y eterno (1640) came to be translated and printed in the Paraguay reductions in 1705, the significance it holds in the transmission of Iberian asceticism to the American missions and how Juan Yaparí and other Guaraní craftsmen participated in its printing and enhanced its illustration. It situates the Guaraní imprint within the context of early modern mission practices and the book-trade of Counter-Reformation Europe, and seeks to show how -in what some scholars consider to be a collaborative enterprise between missionaries of the Society of Jesus and the tribal peoples- the Guaraní edition of the treatise sheds light on the vast global network the Jesuits established in their transmission of faith and knowledge between Europe, Asia, and the Americas.
\end{abstract}

\section{Keywords}

Guaraní printing - Jesuit missions - reducciones - Juan Eusebio Nieremberg - early modern book trade - Spanish asceticism - Paraguay - global network

\section{Introduction}

The ascetical treatise De la diferencia entre lo temporaly eterno by the Spanish Jesuit Juan Eusebio Nieremberg $\left(1595^{-1658)}\right.$ holds a prominent place in the

(C) D. SCOTT HENDRICKSON, 2018 | DOI:10.1163/22141332-00504006

This is an open access article distributed under the terms of the prevailing CC-BY-NC license at the time of publication. 
history of printing in Latin America. ${ }^{1}$ In 1705 , it became the third book to be produced on the first printing press in the Río de la Plata region. ${ }^{2}$ It remains an exquisite example of a text that not only was the first to be printed in the Guaraní language, but was printed at the Jesuit reductions of Paraguay by Guaraní craftsmen, who also created several copper-plate engravings for its illustration. Originally published in Madrid in 1640 and first illustrated in Antwerp in 1684, the Spanish version became a bestseller of religious and devotional literature in Spain. The text was reproduced in at least fifty-four editions in Spanish, and was translated into several European languages in the seventeenth and eighteenth centuries. ${ }^{3}$ Because it incorporated both visual and oral methods of communication within the text, Jesuit preachers and missionaries found the treatise a valuable resource for sermons and catechetical instruction in Spain, and later in the reductions. ${ }^{4}$ In 1754 , the Jesuit mission priest Pedro de Calatayud

1 Juan Eusebio Nieremberg, De la diferencia entre lo temporal y eterno [1640], ... traducido en lengua Guarani por el Padre Joseph Serrano (Doctrinas [Loreto], 1705). Two copies of the text are located in or near Buenos Aires. One is part of a private collection, the other is held at the Complejo Museográfico Provincial Enrique Udaondo in Luján. Incomplete editions are also found at the Archivo Nacional de Asunción in Paraguay, and the Archivum Romanum of the Society of Jesus. Citations and images for this article come from the copy held in Luján. In 2010, the Luján edition was printed in a facsimile edition by the Instituto Bonaerense de Numismática y Antigüedades. An earlier version of this article was first presented at the Legacies of the Book symposium, hosted by the Ricci Institute at the University of San Francisco's Center for the Pacific Rim (September 24-26, 2010).

2 The Río de la Plata included the territories of present-day Paraguay, Uruguay, and Argentina, as well as some border regions of Bolivia and Brazil, and, during the first few years of the seventeenth century, a section of southern Chile.

3 Ignacio Iparraguirre, "Un escritor ascético olvidado: El Padre Juan Eusebio Nieremberg (1595-1658)," Estudios eclesiásticos 32, no. 127 (1958): 427-48, here 433-34; see also Carlos Sommervogel, Bibliothèque de la Compagnie de Jésus, réimpression (Heverlee-Leuven: Editions de la Bibliothèque $\mathrm{SJ}$, [1869-76] 1960), 5:1725-66; and Ludwig Koch, Jesuiten-Lexikon: Die Gesellschaft Jesu einst und jetzt (Heverlee-Leuven: Verlag der Bibliothek SJ, 1962), 2:129596. According to Antonio Astráin, the treatise was widely used by priests for preaching and came to be known more familiarly by the name of the author, the Eusebio; Historia de la Compañía de Jesús en la asistencia de España (Madrid: Razón y Fe, 1916), 5:97. It should also be noted that in the same year Nieremberg published a popular catechism, Práctica del catecismo romano (Madrid: Diego Díaz de la Carrera, 1640), which too was used for preaching and catechetical lessons, and is also cited as the Eusebio, or the Catecismo de Eusebio; see Luis Resines, La catequesis en España: Historia y textos (Madrid: Biblioteca de Autores Cristianos, 1997), 351-52.

4 See Federico Palomo's chapter, "Algo más que la divina gracia: La cultura literaria de los misioneros de interior jesuitas en la Península Ibérica (siglos XVI y XVII)," in La memoria de los 
(1689-1773) continued to recommend that priests and itinerant preachers in the Spanish countryside read De la diferencia as a way to prepare their homilies and lessons. ${ }^{5}$ Calatayud praised the treatise for its efficacy in "treating" and "healing" the Christian conscience. ${ }^{6}$ This article seeks to examine the cultural significance of Nieremberg's treatise through the medium of printing, and why it came to be printed at the reductions. The Guaraní edition shows how printing at the reductions both adopted and adapted the text and its engravings for catechetical practices. But it also exemplifies how significant elements of early modern Spanish asceticism were transmitted and transcribed in word and picture from Madrid and Antwerp to the Paraguay missions. The treatise clearly presents many tenets of the Catholic faith and doctrine, but the history of its printing also brings to light some of the related social, literary, and commercial factors that defined the Iberian book-trade in Europe and the Americas. By viewing this imprint in its original cultural context of seventeenth-century Spanish asceticism, I hope to clarify its communicative appeal, and how it came to be esteemed as a valuable resource to the Jesuits in what John W. O'Malley has described as their multi-faceted "ministries of the word."

\section{Nieremberg and the New World}

Juan Eusebio Nieremberg was born in Madrid in 1595 to parents of German origin. The young couple had come to Spain in 1581 as part of the entourage of María de Austria (1528-1603), daughter of Charles V and sister of Philip II of Spain, who returned to the Spanish capital after the death of her husband, the Emperor Maximilian II. Nieremberg spent most of his life, first as a student, then as a teacher and confessor, at the Imperial College of the Jesuits in Madrid. Having entered the Society of Jesus in 1614 during a brief period at the university in Salamanca, he soon returned to Madrid, where he would eventually write some eighty treatises in both Spanish and Latin. He never served as a missionary, yet his interest, and even influence, in the Jesuit missions and the

libros: Estudios sobre la historia del escrito y de la lectura en Europa y América, ed. María Isabel de Páiz Hernández (Salamanca: Instituto de Historia del Libro y de la Lectura, 2004), 2:113-31.

5 See Pedro de Calatayud, Misiones y sermones: Arte, y método con que las establece (Madrid: Eugenio Bieco, 1754), 1:84.

6 Calatayud states: "Para el arte de meditar, y sanar las conciencias es menester la elección de libros: La Diferencia entre lo temporal y eterno del Padre Nieremberg," and includes the following titles in his list: the Guía de pecadores (1556) by Fray Luis de Granada and the Ejercicios espirituales (1548) by Ignatius of Loyola; 1:84.

7 John W. O'Malley, "Ministries of the Word of God," in The First Jesuits (Cambridge, MA: Harvard University Press, 1993), 91-133. 
New World is reflected in his literary production. Nieremberg's biographer, the Jesuit Alonso de Andrade (1590-1672), claims that the young Juan Eusebio had offered to go to the Paraguay mission. ${ }^{8}$ Although his religious superiors preferred to train him for an academic post at the Colegio Imperial, Nieremberg maintained interest in the American missions. In 1631, he published the Historia panegyrica, considered to be one of the first written reports about the Jesuit missionaries Roque González (1576-1628), Alfonso Rodríguez (1598-1628), and Juan del Castillo (1596-1628), who were martyred in the reductions in $1628 .^{9}$ Nieremberg and Castillo were companions in the earliest stages of their formation as novices in the Jesuit order, and the account of the martyrs was most likely related to him by the Italian Jesuit missionary Giovanni Battista Ferrusino (1581-1655), who passed through Madrid in the 1630 s. $^{10}$ Ferrusino had travelled to Europe as a representative of the Paraguay mission in order to meet with the Society's Father General Muzio Vitelleschi (1563-1645), and among his requests for the progress of the Jesuits' work in the reductions was one for establishing a printing press. ${ }^{11}$

Revealing a continued curiosity about the Americas, Nieremberg published the Historia naturae, maxime peregrinae in 1635 . This book is his detailed

8 Alonso de Andrade, Varones ilustres de la Compañía de Jesús, Tomo v [1666] (Bilbao: El Mensajero del Corazón de Jesús, 1887-92), 8:711. Andrade wrote a hagiographical account of Nieremberg's life soon after his death, first published as "Breve relación de la vida del Padre Juan Eusebio Nieremberg," in Vida del Venerable Padre Francisco Aguado (Madrid: José Fernández de Buendía, 1658). Hughes Didier attests that there is no record in the archives of the Society of Jesus of Nieremberg's request to go to the Paraguay mission; Vida y pensamiento de Juan E. Nieremberg (Madrid: Universidad Pontificia de Salamanca, 1976), 52-53. For more on Nieremberg, see Didier, "Vida de Juan Eusebio Nieremberg," 40-69; Iparraguirre, "Un escritor ascético olvidado," 427-48; and D. Scott Hendrickson, Jesuit Polymath of Madrid: The Literary Enterprise of Juan Eusebio Nieremberg (1595-1658) (Leiden: Brill, 2015), 9-50.

9 Juan Eusebio Nieremberg, Historia panegyrica, de tribus gloriosis martyribus, ex eadem Societate Iesu, nuper in Uruguaï pro fide occisis; quorum martyry gloriam multa prodigia significarunt, in De arte voluntatis, libri sex (Lyon: Jacques Cardon, 1631), 7-44. The treatise was edited more recently by W. Michael Mathes, Primeras noticias de los protomártires de Paraquaria: La Historia panegírica de Juan Eusebio Nieremberg (Guadalajara: CAREM, 2004).

$10 \quad$ Mathes, "Introducción," 26.

11 The Italian missionary Giovanni Battista Ferrusino was elected procurator of the Province of Paraguay in 1632. This granted him the possibility to travel to Madrid and Rome between $163_{2}$ and 1638; see Pablo Pastells, Historia de la Compañía de Jesús en la Provincia del Paraguay (Madrid: Victoriano Suárez, 1915), 2:516; see also Hugo Storni, Catálogo de los jesuitas de la Provincia del Paraguay, 1585-1786 (Rome: Institutum Historicum Societatis Iesu, 1980), 101. 
account of the flora and fauna of the New World, and it reflects Spain's fascination in the sixteenth and seventeenth centuries with the exotic American environment and its indigenous peoples. In 1590, the Jesuit José de Acosta (1539-1600) had published his famous Historia natural y moral de las Indias, which would become the precursor of many similar works. Nieremberg's Historia naturae documents the plants and animals of the New World, and describes many of these in the context of their religious significance, such as the existence of the bird of paradise (see Ledezma, who explains how such nonAmerican items appear in the volume). Since certain types of this bird were thought to have no feet, which meant that it could not rest on anything material and earthly, Nieremberg identifies its continuous flight upward as a symbol of virtue and evangelical poverty. ${ }^{12}$ Much of the text is a spiritual exegesis of the natural world, with the aim of deciphering the hand of the Creator in the mysterious lands of the American Indies. ${ }^{13}$

The New World had clearly captured Nieremberg's attention. But his texts also became a source of inspiration for missionaries in Paraguay. There were a total of twenty-one books written by Nieremberg in the Jesuit library in Asunción before the suppression of the Society of Jesus in the Spanish Americas in $1767 .{ }^{14}$ This figure does not take into account the other copies of his works that

12 Juan Eusebio Nieremberg, Historia naturae, maxime peregrinae (Antwerp: Officina Plantiniana, 1635), 210; see also Nieremberg's manuals on natural philosophy: Curiosa filosofía, y tesoro de maravillas de la naturaleza (Madrid: Imprenta del Reino, 1630), and Oculta filosofía, de la simpatía y antipatía de las cosas, artificio de la naturaleza, y noticia natural del mundo (Madrid: Imprenta del Reino, 1633). He describes the bird of paradise in "Prolusión a la doctrina y historia natural" [1629], in Curiosa filosofía (Madrid: Imprenta del Reino, 1634), $218^{\mathrm{r}}-48^{\mathrm{v}}$, here $226^{\mathrm{r}}, 237^{\mathrm{v}}-38^{\mathrm{r}}$. For more on Nieremberg's Historia naturae and the inclusion of the bird of paradise in it, see Domingo Ledezma, "Una legitimación imaginativa del Nuevo Mundo: La Historia naturae, maxime peregrinae del jesuita Juan Eusebio Nieremberg," in El saber de los jesuitas: Historias naturales y el Nuevo Mundo, ed. Luis Millones Figueroa and Domingo Ledezma (Frankfurt: Vervuert, 2005), 53-83.

13 For more on the Jesuit approach to interpreting nature in the early modern period, see Ralph Dekoninck's chapter, "Imaginar la ciencia: La cultura emblemática jesuita; Entre ars rhetorica y scientia imaginum," in Escrituras de la modernidad: Los jesuitas entre cultura retórica y cultura científica, ed. Perla Chinchilla and Antonella Romano (Mexico City: Universidad Iberoamericana, 2008), 143-57, here 148-57. For more on Nieremberg as a natural philosopher, see Hendrickson, Jesuit Polymath of Madrid, 86-125; and José Ramón Marcaida López, Arte y ciencia en el barroco español (Seville: Fundación Focus Abengoa / Madrid: Marcial Pons, 2014), 117-32, 170-80.

14 Fernando Gil, "Introducción," in De la diferencia entre lo temporal y eterno ... traducido en lengua Guaraní [1705], ed. facsimile (Buenos Aires: Instituto Bonaerense de Numismática y Antigüedades, 2010), xxv-lxx, here xxxii-xxxiii. 
may have existed in the libraries of the various reductions, such as the one at Candelaria. His semi-mystical treatise, De la hermosura de Dios (Madrid, 1641), was one of the main literary influences for the Peruvian Jesuit Antonio Ruiz de Montoya (1585-1652), who sought to emulate Nieremberg's style in his Silex del divino amor. ${ }^{15}$ Like his predecessor Ferrusino, Montoya visited Madrid as a representative of the missions in the early 1640 , and he came into contact with Nieremberg at the very moment when both De la hermosura de Dios and De la diferencia entre lo temporal y eterno were published.

Written as a compilation of five books, Nieremberg's De la diferencia expounds the benefits of the ascetical life and urges the reader to reject the trappings of the temporal world. Rather than investing in material riches and honors, which lead only to eternal damnation, the faithful Christian must aim to gain the everlasting treasures of heaven. Although the treatise portrays important elements of Catholic faith and doctrine, such as the efficacy of the sacraments and the practice of penance, it is not a catechism. It is a spiritual guide for understanding the temporal world not as an end in itself, but as a means to the greater end of eternal salvation. The Jesuit José Serrano (1634-1713) completed the Guaraní translation of Nieremberg's treatise in the reductions by $1694 \cdot{ }^{16}$ But it was not until eleven years later that the treatise would be printed on the mission press, three quarters of a century after Ferrusino's request.

15 Ruiz de Montoya's treatise remained in manuscript form until it was printed in 1991: Sílex del divino amor y rapto activo del anima en la memoria, ed. José Luis Rouillón Arróspide (Lima: Pontificia Universidad Católica del Perú, 1991). See also Carlos Alberto González, "El Sílex del divino amor de Antonio Ruiz de Montoya: El testimonio místico de un misionero entre los Guaraníes," Teología 75, no. 1 (2000): 29-73. Regarding Ruiz de Montoya's Conquista espiritual (Madrid, 1639), Clement J. McNaspy suggests that the author "unsuccessfully attempted to have his book ghost-written for him by the leading Jesuit writer of the time, Eusebio Nieremberg"; see McNaspy's "Introduction," in Antonio Ruiz de Montoya, The Spiritual Conquest, ed. and trans. Clement J. McNaspy, John P. Leonard, and Martin E. Palmer (St. Louis, MO: Institute of Jesuit Sources, 1993), 22; see also Barbara Ganson, "Antonio Ruiz de Montoya, Apostle of the Guaraní," Journal of Jesuit Studies 3, no. 2 (2016): 197-210; The Spiritual Conquest: Early Years of the Jesuit Missions in Paraguay, ed. and trans. Barbara A. Ganson and Clinia M. Saffi (Chestnut Hill: Institute of Jesuit Sources, 2017); and "Antonio Ruiz de Montoya," in Diccionario histórico de la Compañía de Jesús, ed. Charles O'Neill and Joaquín M. a Domínguez (Rome: Institutum Historicum Societatis Iesu / Madrid: Universidad Pontificia de Comillas, 2001), 4:3436-37.

16 See Joseph Serrano, "Al M[uy] R[everendo] P[adre] Tirso González, Prepósito de la Compañía de Jesús," in De la diferencia (Doctrinas [Loreto], 1705), ๆ10v. For a more in-depth analysis of the structure and the currents of thought in De la diferencia entre lo temporal y eterno, see Didier, Vida y pensamiento, 156-206; and Hendrickson, Jesuit Polymath of Madrid, 126-62. 


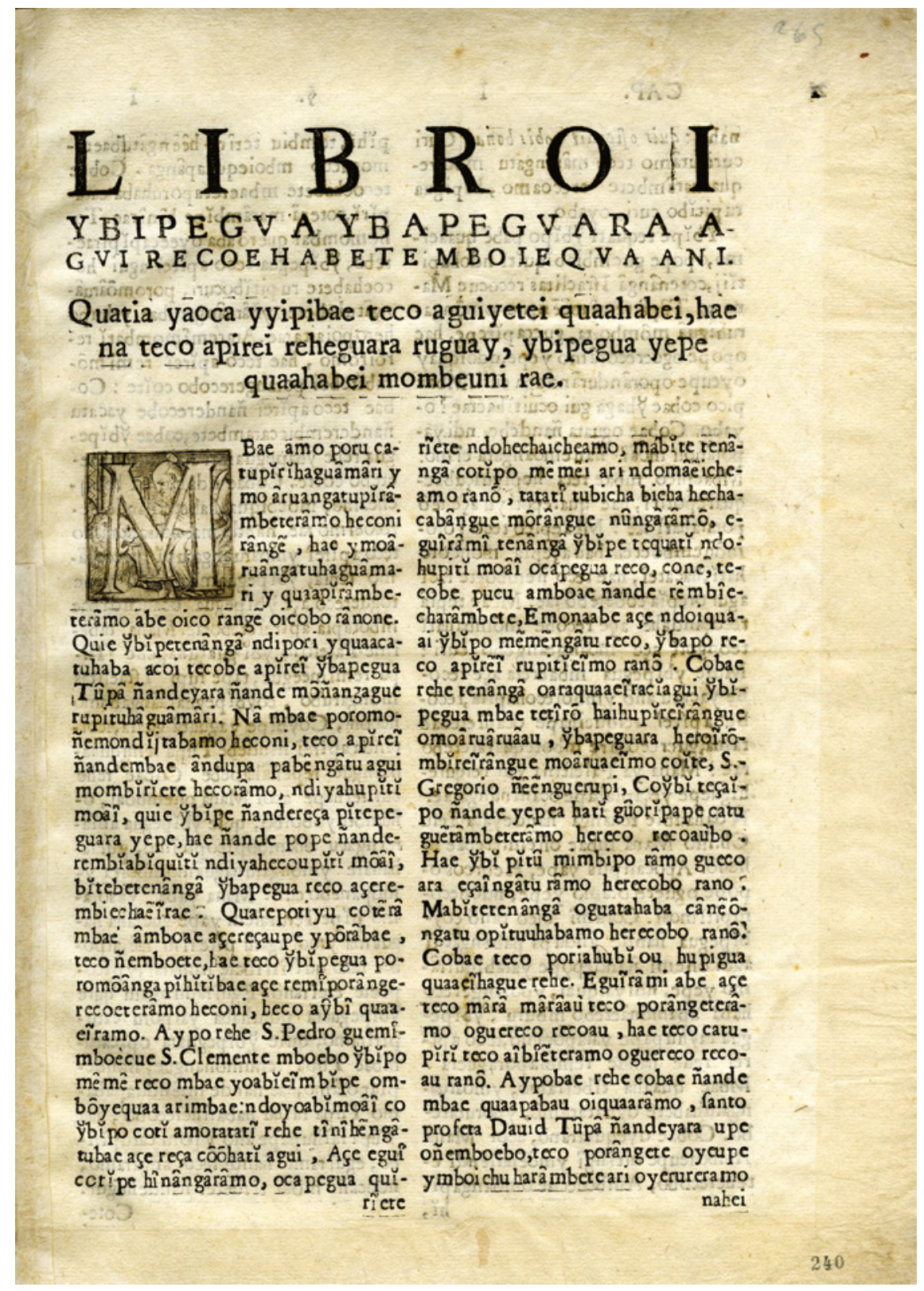

FIGURE 1 Guaraní typescript (Guaraní edition, Book1, page 1) 
The press was established with the arrival of the Viennese Jesuit Juan Bautista Neumann (1659-1704), who was sent to Paraguay in 1691 for this purpose. Neumann and Serrano inaugurated the press in 1700 by printing a Spanish edition of the Martirologio romano, which had been translated from the original Latin in 1586 by the Jesuit Dionisio Vázquez (1528-89). ${ }^{17}$ Equally important was the subsequent printing in 1703 of the Flos sanctorum by the Society's Pedro de Ribadeneyra (1527-1611), which was also translated by Serrano into Guaraní. The Flos sanctorum was the first text to be printed in this language in the Río de la Plata region. Nieremberg's book, which had a wide circulation in Spain and other European countries, must have been considered a valuable resource for the Jesuit missionaries in the Americas, as manuscripts of it were also prepared in the Chiquita and Mexica languages for the missions in what are present-day Bolivia and Mexico. ${ }^{18}$ While Nieremberg most likely never ventured too far from the colegio where he lived and taught, his literary connection to the reductions is not insignificant, and his famous treatise assumed, as will be seen, the voice of a mission preacher. Nieremberg may have desired to go to Paraguay, but it was through his text that he acted as a long-distance missionary,

17 Guillermo Furlong, Historia y bibliografía de las primeras imprentas rioplatenses, 1700-1850 (Buenos Aires: Editorial Guarania, 1953), 1:57. An extant copy of the Martirologio (Loreto, 1700) was recently identified at the archives in Concepción de Chiquitos, Bolivia: Ernesto Maeder, "El Martirologio romano: Hallazgo del primer libro impreso en el Río de la Plata," Idea viva: Gaceta de cultura 9 (2001): 17-18, 46; see also Maeder, "Libros, bibliotecas, control de lecturas e imprentas rioplatenses en los siglos XVI al XVIII," Teología 40, no. 77 (2001): 5-24; and René Krüger, "La imprenta misionera jesuítico-guaraní y el primer libro rioplatense, Martirologio romano de 1700," Cuadernos de teología 29 (2010): 1-27. According to Krüger, the mission text is based on an edition printed in Madrid in 1661 (12). Dionisio Vázquez originally published the Martirologio romano: Traducido de la lengua latina a la española in 1586 in Valladolid, Spain, which saw subsequent printings in Madrid (1587) and Valladolid (1596). The seventeenth-century text, bearing the title Martirologio romano: Reformado conforme a la nueva razón del calendario, y verdad de la historia eclesiástica, is a reedited version of the earlier one by Vázquez: see "Denis Vasquez," in Sommervogel, 8:486-87. For a more recent typology of the books printed on the mission press, which operated until 1727, see Guillermo Wilde, "Adaptaciones y apropiaciones en una cultura textual de frontera: Impresos misionales del Paraguay jesuítico," História Unisinos 18, no. 2 (2014): 270-86.

18 See José Toribio Medina, Historia y bibliografía de la imprenta en el antiguo Virreinato del Río de la Plata [1892], reprint series (Amsterdam: N. Israel, 1965), 10; and Furlong, Historia $y$ bibliografia, 320 . The manuscripts of these translations are listed in the bibliographies of their respective translators in Sommervogel: "Ignace Chomé," 2:1155-56; and "Jean Gummersach," 3:1950-51; see also "Ignace Chomé," in Diccionario histórico de la Compañía de Jesús, 1:790-91. 
removed, in the words of Fernando Bouza, both in space and time. ${ }^{19}$ That the treatise was translated into at least three Amerindian languages, and that it was one of the first books to be printed on the new Guaraní press, suggests that it was an important resource for the missionaries.

How, therefore, did it emerge as one of the preferred texts in the Jesuit method of evangelization? The reason, according to historian Fernando Gil, is due mainly to the prestige the book had earned in Spain and throughout Europe. ${ }^{20}$ While this is certainly true, other aspects of the treatise, namely its function as a catechetical tool of the Jesuits and its relationship to their international network of printed and illustrated resources, remains to be fully understood. I shall address these two points in the following sections.

\section{Iconographical Interpretations}

Scholarship in the history of printing in Latin America continues to highlight the significance of the Guaraní edition of Nieremberg's treatise, not least because it was a collaborative project between the Jesuits and the indigenous neophytes. Serrano stresses this point in the dedication of his translation by admiring the skill of the Guaraní craftsmen, who participated as the "instrumentos" of its production. ${ }^{21}$ In 1684 , a new Spanish edition had been printed in Antwerp with the inclusion of twelve copper-plate illustrations by the Flemish engraver Gaspar Bouttats (1640-95). ${ }^{22}$ Although it is not clear which edition Serrano used for his translation, it is most probable that he had access to this Antwerp edition. The Guaraní artisans reproduced and modified the Bouttats illustrations for the mission plates, but they also created several more, bringing the new total to forty-three. ${ }^{23}$ While Serrano makes note of this collective

19 See Fernando Bouza, Papeles y opinión: Políticas de publicación en el Siglo de Oro (Madrid: Consejo Superior de Investigaciones Científicas, 2008), 45-66.

20 Gil, "Introducción," xxxix.

21 According to Serrano, "Pues así la imprenta, como las muchas láminas para su realce han sido obra del dedo de Dios, tanto más admirable, cuanto los instrumentos son unos pobres indios nuevos en la fe, y sin la dirección de los maestros de la Europa, para que conste que todo es favor del cielo, que quiso con medio tan inopinado enseñar a estos pobres las verdades de la fe," Nieremberg, De la diferencia (1705), $₫ 11^{\mathrm{r}}$.

22 Emmanuel Bénézit, "Caspar (Gaspar) Bouttats," in Dictionnaire critique et documentaire des peintures, sculpteurs, dessinateurs et graveurs, nouvelle édition (Paris: Librairie Gründ, 1976), 249 .

23 The edition at the Museo Enrique Udaondo in Luján contains forty-two engravings. In his summary of the critical scholarship on the text, Ricardo González reiterates that the copy 


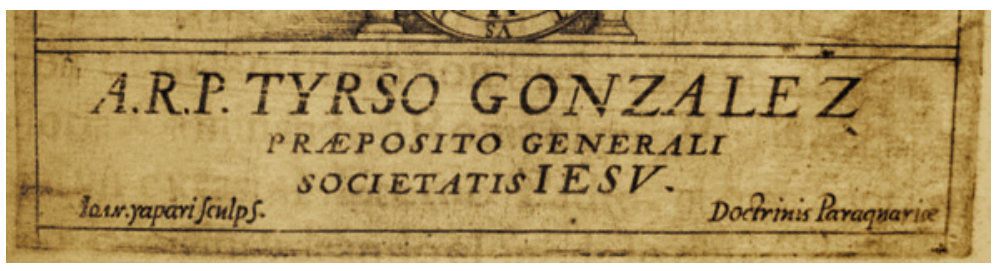

FIGURE 2 Detail (Guaraní edition, front-matter, plate 9)

Guaraní contribution, only one of the plates bears a Guaraní name, that of Joan Yaparí, who today must represent the other artists of the workshop. According to art historian Josefina Plá, prior to installing the press the Jesuits had trained the Indians to copy and illustrate manuscripts for their liturgical and catechetical practices. ${ }^{24}$ They performed this task with great skill. But Yapari's signature signifies something else beyond the corporate identity of the artisans. It represents the transmission and translation of images from one culture to another.

The Bouttats illustrations appear to be designed specifically for the Antwerp edition of the treatise, since they correspond to the themes and topics of the adjacent textual passages. One of the engravings in Book 1, for example, includes a combination of images depicting several tales and parables told by Nieremberg in order to portray the meaning of human mortality and the dangers of worldly delights. While many of these tales are connected, as will be noted, to longstanding oral tradition, I will first discuss the significance of their visual representation in the engravings. The central image in the plate is that of a young man who is suspended over the opening of a cave. Supporting himself by the branch of a tree, the precarious situation of the youth depicts a parable known as the "allegory of human life." 25 According to Nieremberg's explanation

held privately in Buenos Aires includes one extra engraving, "Textos e imágenes para la salvación: La edición misionera de La diferencia entre lo temporal y eterno," ArtCultura 11, no. 18 (2009): 137-158, here 141-42.

24 Josefina Plá, "El grabado en las misiones jesuíticas," Cuadernos hispanoamericanos 198 (1966): 577-92, here $580-82$.

25 Juan Eusebio Nieremberg, De la diferencia entre lo temporal y eterno [1640], in Obras escogidas del R.P. Juan Eusebio Nieremberg, ed. Eduardo Zepeda-Henríquez (Madrid: Atlas, 1957), 2:2-291, here 11-12; see also Santiago Sebastián, "Lectura iconográfica de la versión guaraní del libro del padre Nieremberg, De la diferencia entre lo temporal y eterno," Boletín del Museo e Instituto Camón Aznar 48-49 (1992): 309-28, here 311. Nieremberg cites the eighth-century monk John of Damascus as the source of the allegory, while it is also identified as a tale from the medieval novel Barlaam and Josaphat; see John Knipping, Iconography of the Counter-Reformation in the Netherlands: Heaven and Earth (Nieuwkoop: B. de Graaf, 1974), 69. 


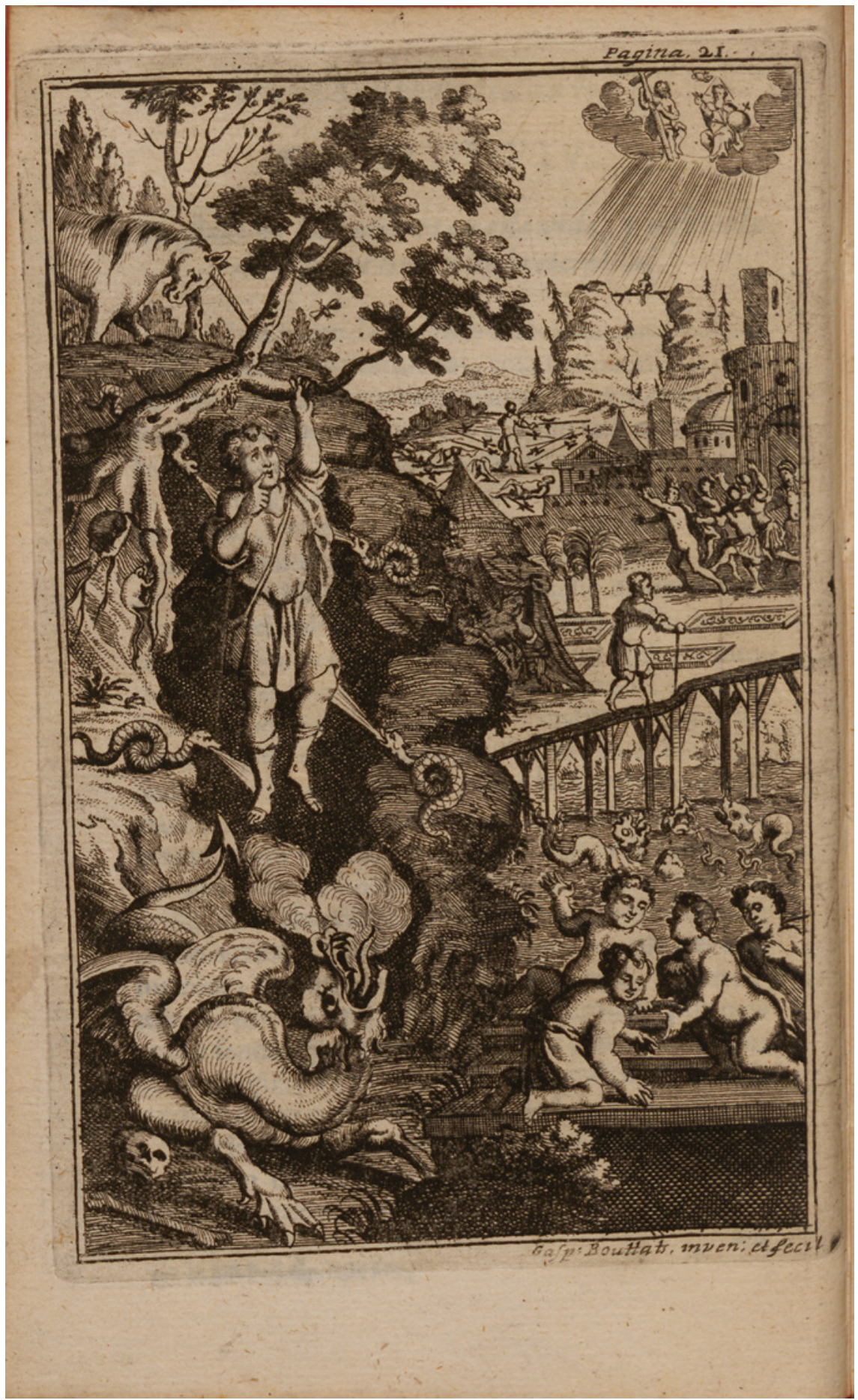

FIGURE 3 "Allegory of Life" (Antwerp edition, Bouttats plate 21) 
of the parable, the young man has been pursued by death since the day of his birth, which is represented in the figure of the unicorn that looms over him. While death has not yet reached him, the young man risks falling into the snare of the dragon below. In the context of the parable, he faces the possibility of eternal banishment in hell.

Nieremberg identifies the scene as human existence in the temporal world, replete with its distractions and temptations. Even though death may be imminent, the youth is most concerned with the delights of the world. This is depicted as he savors the sweet honey that drips from the leaves of the tree. Rather than having concern for the salvation of his soul, he gives in to the demands of his passions, thereby ignoring the threat of eternal suffering. The surrounding images similarly portray the fragility of life and the precarious nature of human existence on earth. The children in the foreground play near the openings of what appear to be tombs, while behind them a man crosses a narrow bridge over waters teeming with sea monsters. ${ }^{26}$ The slightest distraction will send them all falling to their death. The image of a naked man wearing only a crown on his head depicts Nieremberg's version of a medieval moral tale about a king who is stripped of his power and his possessions. His situation portrays the passage from the temporal world to the eternal, where material goods have no meaning. ${ }^{27}$ In the background, a person suspended on a plank between two high mountain peaks illustrates yet another passage concerning human vulnerability and the inevitability of death. Here Nieremberg equates human existence to the perilous journey across the narrow bridge as the traveler is assaulted by strong winds. ${ }^{28}$

In comparison, the plates in the mission edition demonstrate how the Guaraní artists copied many of these same details, such as the illustration of the allegory and the scene of the mountain peaks in plate twelve. The allegory appears largely as in the original, although the mountain peaks are enlarged. Both the Antwerp and the mission engravings include an image of the Holy Trinity in the upper section of the plate, which clearly serves to illuminate the Christian context of the imagery. But other engravings by the Indians portray

$26 \quad$ Nieremberg, De la diferencia entre lo temporal y eterno (1957), 6, 11, and 248.

27 Nieremberg, 13-14.

28 Nieremberg, 10. Here the author asks: “¿Cómo pudiera dormir a quien sólo le sirviese de puente entre dos altísimos peñascos un estrecho madero de medio pie de ancho, corriendo mientras pasaban vientos fortísimos, y viendo que se podía caer en un horrendo despeñadero?" [How could anyone ever even sleep who knowingly had only a thin wooden plank half a foot wide for a bridge to cross, running between two high peaks with the strongest of cross-winds blowing, and seeing how easy it is to go into a horrendous fall?]. 


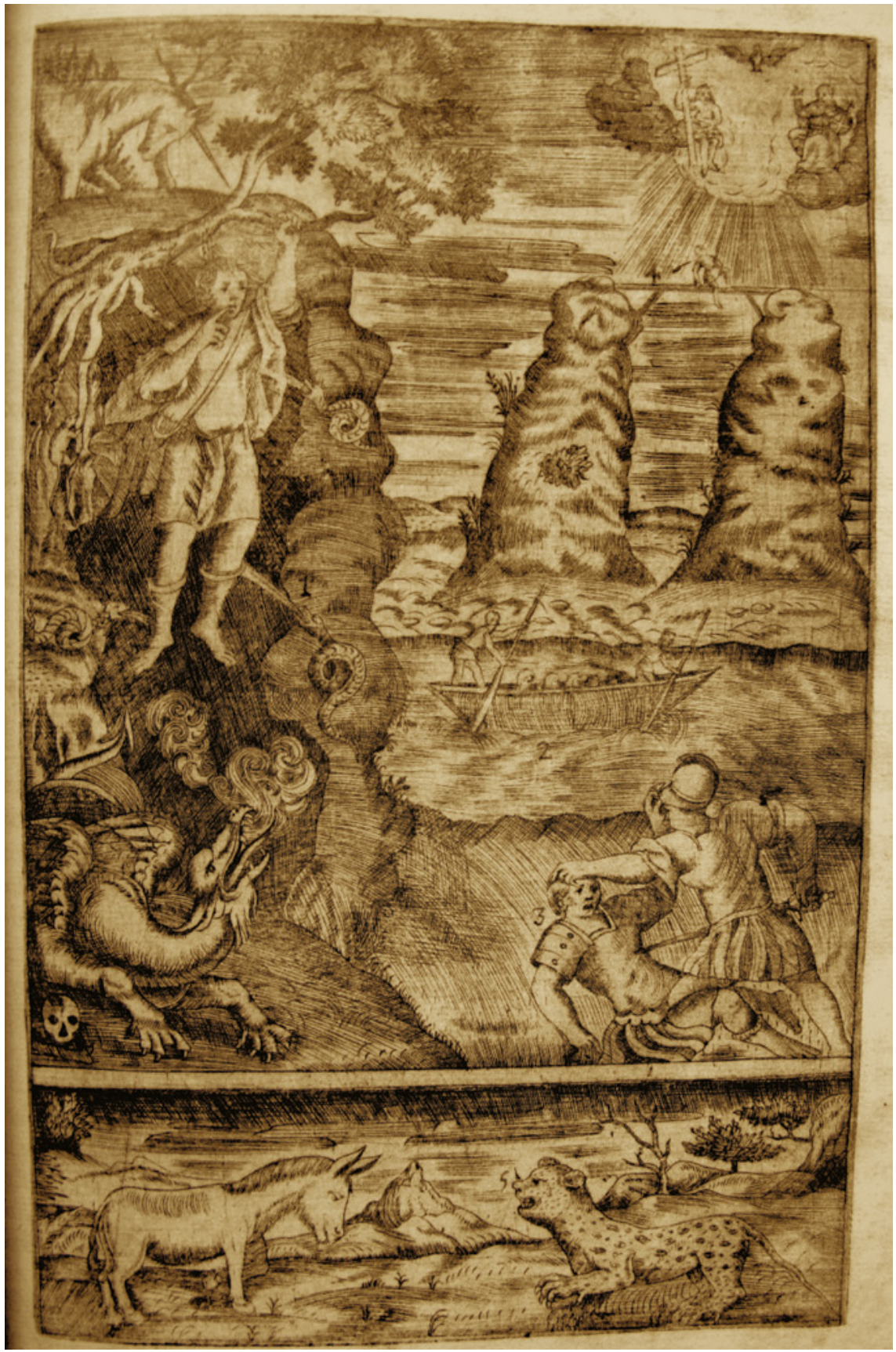

FIGURE 4 "Allegory of Life" (Guaraní edition, Book 1, plate 12) 


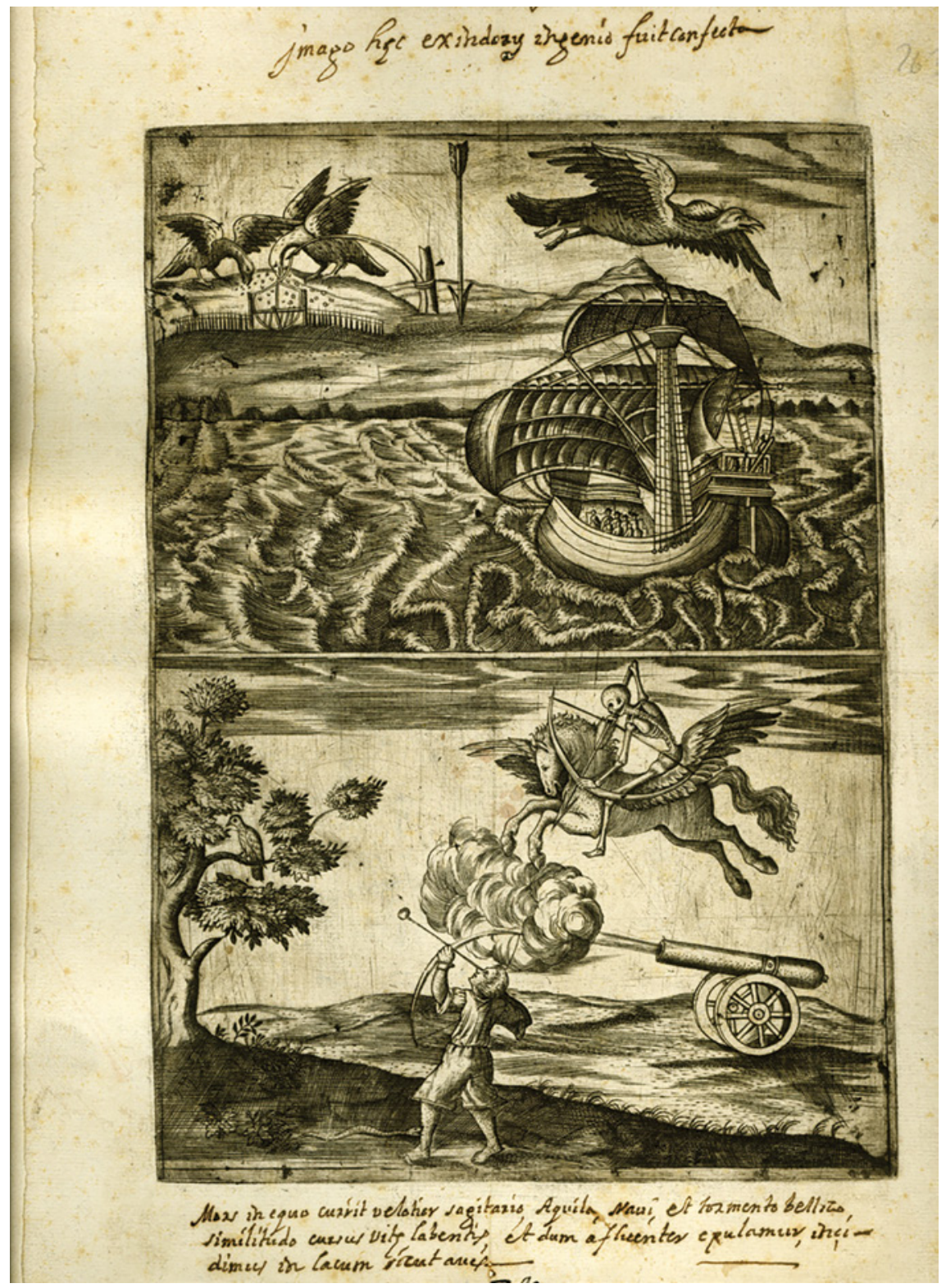

FIGURE 5 "Prowess of Death"(Guaraní edition, Book 1, plate 46) 
passages from the text not found in the plates by Bouttats. Plate forty-six, for example, depicts a display of several images described by Nieremberg in order to emphasize the swift prowess of death. The blast of a cannon and the impending flight of the arrow in the hunter's bow in the lower portion of the plate relate to the image of death, which quickly flies through the sky on a winged horse and arrives without notice. The figure of Death aims an arrow at the hunter just as the hunter seeks his prey. Death is imminent for the man, who also is about to be bitten in the leg by an approaching snake. In the upper section of the plate the arrow - the instrument of death-is portrayed with prominence. In the upper panel, the people in the ship are at the complete mercy of the tossing sea as a large bird hovers above. The bird overshadows the boat much the same way death rides over the hunter in the bottom half of the illustration. ${ }^{29}$ This plate was not copied from the Antwerp edition, yet depicts a collage of images described by Nieremberg.

The Guaraní engravings also include some elements of their own. Plate twelve replicates the depictions of the allegory and other images in the Bouttats engraving, yet the scene of the man crossing a bridge has been replaced by a group of Amerindians in a thatched boat, while the image of the children, like the bridge, has been transcribed to another engraving. There is also an entirely new panel depicting the encounter between a donkey and a jaguar inserted below the main illustration. These adaptations are significant, such as the inclusion of the jaguar, because they show how the Indians inserted elements of their own ethos into the plates, relating the illustrations more closely to the local Guaraní culture of the jungle missions and reflecting, in their own visual expression of the text, aspects of the Guaraní worldview. ${ }^{30}$

According to Plá, the artists created images more closely related to their natural surroundings, while at the same time they began to portray their own ethnic identity. ${ }^{31}$ Naturalistic elements receive greater emphasis, as seen in the panel with the donkey and the jaguar. Likewise, the plates depict other animals, such as the snake and the rooster in plate six. The snake was not an uncommon

29 See also Gil, "Introducción," xlvii.

3o González places emphasis on the "local" or "naturalistic" features of the engravings, "Textos e imágenes para la salvación," 137-58; see also Franz Obermeier, "Der argentinische Erstdruck Nierembergs De la diferencia in Guarani im Kontext der Bilderzyklen, Lateinamerika im 18. Jahrhundert, Art-Dok. Publikationsplattform Kunstgeschichte (2006): 1-66, doi: http://doi.org/10.11588/artdok.0oooo154.

31 Plá, "El grabado en las misiones jesuíticas," $585^{-86}$; see also Plá's more detailed study, $E l$ barroco hispano-guaraní, in Historia cultural: Obras completas, ed. Miguel A. Fernández (Asunción: Instituto de Cooperación Iberoamericana, 1991), 2:121-327, here 158, 260-63. 


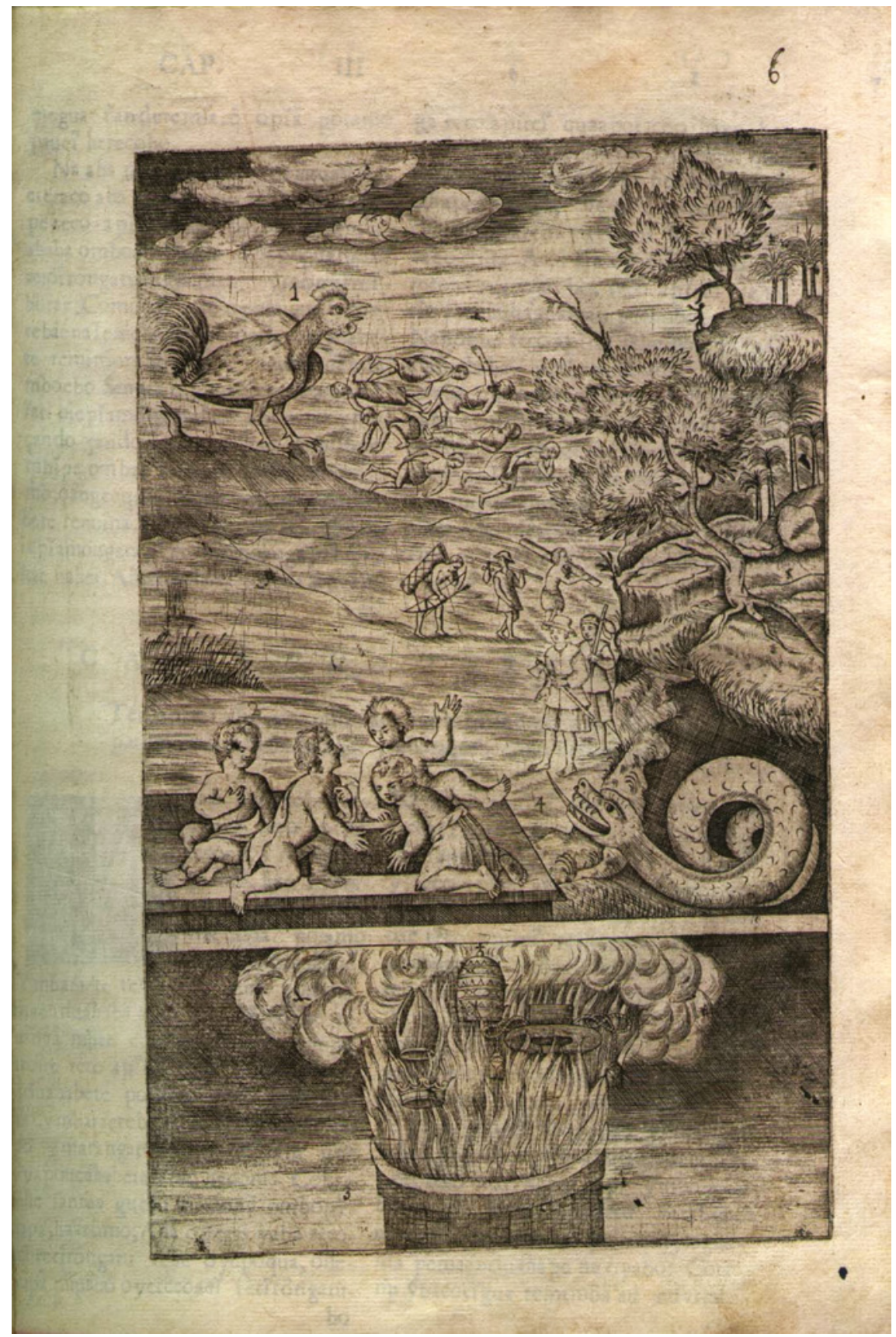

FIGURE 6 "Details of Animals" (Guarani edition, Book 1, plate 6) 
item in European iconography, and its visual significance varied in its usage. ${ }^{32}$ But in the Guaraní rendition the snake appears enlarged and in proportion to those of the jungle rainforest. The image of the children playing on the edge of a tomb has been included here, but in the Guaraní version the snake emerges as a more direct threat to their precarious situation. This plate also depicts a large rooster, which seems to dominate the upper half of the illustration. In European iconography, the rooster was often used to symbolize vigilance. ${ }^{33}$ Here it seems to sound a similar warning regarding the power of death as it crows over the corpses of several Indians. Like the snake, the naturalistic element of the animal is given great prominence. A figure of what appears to be a monkey can also be seen in the upper right portion of the illustration. In the central part of the plate there is a mixed group of Indians and Europeans walking together: one of the Guaraní natives carries a bow and arrow, while a figure in European garb bears a pilgrim's staff. Other figures in both European and Indian dress carry items of construction, such as an axe and a plank. Their destination is not clear, but the portrayal of their shared journey seems to capture the significance of the mission text, as it represents the blending of languages, iconography, and ethnicity in the encounter between the Jesuit missionaries and the Guaraní neophytes. The illustration exemplifies what some scholars have come to call the "middle ground," or "mission culture," that came to emerge in the interaction between the Jesuits and tribal people. ${ }^{34}$

Through the engravings it is possible to see how the Indians began to assimilate Christian beliefs into their ethos. According to Ricardo González, the artists "reinterpreted" European illustrations in order to reflect their own cultural sensibilities..$^{35}$ But on the other hand, the plates reveal the importance of the visual apparatus employed by the Jesuits in their methods of evangelization. ${ }^{36}$ It was through these visual means and other forms of communication that the Jesuits were able to engage and instruct the neophytes. Art historian Gauvin Bailey attests that visionary experiences "provided a convenient point

32 Knipping, Iconography of the Counter-Reformation, 18. According to the parable, Bouttats includes four snakes in his version of the "allegory of life." They also appear in the Guaraní copy. Nieremberg identifies the snakes as representations of the four elements (earth, air, water, and fire), or temperaments (sanguine, melancholic, choleric, and phlegmatic) of human life; see Nieremberg, De la diferencia (1957), 12.

33 Knipping, Iconography of the Counter-Reformation, 24 and 29.

34 See Wilde, "Adaptaciones y apropiaciones," 272. For more on the socio-religious cultural dynamic in the reductions, see Wilde's more comprehensive study Religión y poder en las misiones de guaraníes (Buenos Aires: Editorial sв, 2009).

35 González, "Textos e imágenes para la salvación," 158.

36 González, "Textos e imágenes para la salvación," 140. 
of convergence for the two cultures, since they were an essential feature both of the Guaraní religion [...] and of early modern Catholicism."37 The method of contemplation and the use of visual imagination designed by Ignatius Loyola (c.1491-1556) for making the meditations of the Spiritual Exercises, for example, emerged as an important component of the Jesuits' catechetical practices. For this they relied on narrative and visual forms of communication to instruct their audiences. Consequently, the Jesuits were able to develop their ministries in the missions by using texts that most effectively engaged the neophytes. In other words, they sought to employ methods of evangelizing in which they could communicate their message in multiple ways. ${ }^{38}$

\section{Forms of Communication: Hearing and Visualizing the Printed Word}

That Nieremberg's treatise was illustrated and printed in a new Spanish edition in Antwerp in 1684 is important to note. Both the time and the place of its publication speak not only of the commercial value of the text, but of its visual appeal. It was printed in the house of Hieronymus Verdussen (1620-87), which had embraced a commercial strategy designed specifically for the Catholic market, and allowed Verdussen to capitalize on the growing demand in Europe for Counter-Reformation books and illustrations. ${ }^{39}$ According to historian Keith Whinnom, printing in Spain during this time period was dominated by works like Nieremberg's, that is, by non-fiction prose of a didactic and devotional nature. ${ }^{40}$ If on one hand the treatise matched the editorial requirements of Verdussen, it also represented the leading literary tastes of seventeenthcentury Spain, especially in regard to religious and ascetical literature.

That the treatise was illustrated with the additional expense of copperplate engravings speaks not only of its visual appeal, the illustrations also relate to the greater communicative function of the text. As the treatise could be read out loud in a public setting, many of the plates served to illuminate

37 Gauvin Bailey, Art and the Jesuit Missions in Asia and Latin America (Toronto: University of Toronto Press, 1999), 152.

38 O'Malley, First Jesuits, 91-133.

39 Stijn van Rossem, "La imprenta de los Verdussen y la comercialización de sus libros en el mundo ibérico e iberoamericano," in Un mundo sobre papel:Libros flamencos en el imperio hispanoportugués (siglos XVI y XVII), ed. Werner Thomas and Eddy Stols (Leuven: Acco, 2009), 83-100, here 91-96.

40 Keith Whinnom, "The Problem of the 'Best-Seller' in Spanish Golden-Age Literature," Bulletin of Hispanic Studies 57, no. 3 (1980): 189-98, here 194. 
the admonitions and exhortations of the author. However, this aspect of how it came to be used in the missions represents a shift in the author's intention. Nieremberg had intended his treatise to be a guide for personal prayer and meditation, stating in the introduction that it could be used for the making of "spiritual exercises" during a period of eight to ten days. ${ }^{41}$ In this sense, the text could serve as a type of retreat manual. For this purpose there is a special index of meditations in the front of the book for the reader to follow. According to Gil, Nieremberg's treatise follows the paradigm of Loyola's Spiritual Exercises by placing emphasis on the rejection of personal sin and disorder in the "reforma de vida," the reform of one's life. The "Principle and Foundation," the "Meditations on Hell," and the "Contemplation for Attaining Divine Love" from the Exercises are developed at length by Nieremberg and guide the reader through the text similar to the way in which an exercitant progresses in the Ignatian Exercises. ${ }^{42}$

Nonetheless, the treatise was adopted for other purposes, as it came to be used more publicly for the preaching of sermons and catechetical lessons. It is well known that as the Jesuits continued to develop their apostolic ministries in parishes and rural missions, whether at home or abroad, they found that books and illustrations aided them in their catechetical activities. ${ }^{43}$ Nieremberg's treatise was used in a similar manner, as has been noted above regarding the mission practices of the Jesuit Pedro de Calatayud. ${ }^{44}$ While the treatise could be used as a prayer guide or for devotional reading, its subject matter and, more importantly, its narrative style allowed the text to be experienced in multiple ways. Although it treats elements of church doctrine, the author's narrative style and the ascetical subject matter engage the reader, or the audience, with colorful descriptions and emphatic exhortations on how to embrace the Christian lifestyle. Using verbs in the imperative form, Nieremberg directly addresses the reader, or the listener, who is presented with vivid images. The author therefore engages the audience both aurally and visually. Not only can the printed word be read, but it can be heard and seen. For example, in several occasions Nieremberg exhorts the reader to imagine a shocking portrayal of human mortality and the afterlife. These explicit passages on death depict

\footnotetext{
41 Nieremberg, Práctica del catecismo romano, $95^{\mathrm{v}}$.

42 Gil, "Introducción," xxxviii-xxxix. See also Hendrickson, Jesuit Polymath of Madrid, 157-62.

43 Palomo, "Algo más que la divina gracia," 113-31.

44 See also Plá's comments regarding the use of the book in the reductions, "El grabado en las misiones jesuíticas," 577-92.
} 
the gruesome reality of decomposing and rotten bodies. ${ }^{45}$ Hence, the text engages the visual imagination of the reader in much the same way as a vanitas painting shocks the viewer with its display of images. In his treatment of the postrimerías, the Four Last Things—Death, Judgment, Heaven, and Hell—one only has to recall the rotting corpses depicted in the Jeroglificos de nuestras postrimerías by Juan de Valdés Leal (1622-90), a classic example of vanitas iconography in seventeenth-century Spanish painting. ${ }^{46}$

According to Bouza, printed materials came to be an indispensable resource for mission work in the seventeenth and eighteenth centuries. In the absence of the priest or the catechist, the presence of a book or illustration allowed the mission to continue in operation. ${ }^{47}$ Either publicly or in private, a text could be readily consulted. But while printing and engraving permitted the widespread distribution of texts and images beyond the limited time and space of the missioner, the most effective form of communication was still to be found in the voice. In other words, it was found that the oral delivery of the text allowed the missioner the greatest impact upon an audience. ${ }^{48}$ While many Guaraní individuals would, over time, learn to read and write in Guaraní, Spanish and even Latin, the orality of the treatise granted the Jesuits and their trained catechists from among the indigenous elite the ability to enter into the already existing oral culture of the Guaraní people. ${ }^{49}$

In addition to the exhortations and commands in the text, literary forms of communication include the narration of biblical scenarios and historical

45 For one example in Spanish, see Nieremberg's description of the human corpse compared to that of a worm-eaten dog, De la diferencia (1957), 59.

46 Juan de Valdés Leal painted the Jeroglificos de nuestras postrimerías in 1672 for the Hospital of Charity in Seville. For more information, see Jonathan Brown, Images and Ideas in Seventeenth-Century Spanish Painting (Princeton: Princeton University Press, 1978), 128-46. Worth noting is Valdés Leal's inclusion of Nieremberg's famous treatise in two of his paintings, Alegoría de la vanidad (1660) and Alegoría de la Eucaristía (c.1671), see Hendrickson, Jesuit Polymath of Madrid, 126-31.

47 Bouza, Papeles y opinión, 45-66.

48 See Fernando Bouza, Comunicación, conocimiento y memoria en la España de los siglos XVI y XVII (Salamanca: Seminario de Estudios Medievales y Renacentista / Sociedad Española de Historia del Libro, 1999), 31.

49 For more on the oral and written forms of communication in Guaraní culture both during and after the Jesuit presence in the reductions, see Eduardo Neumann, "Razón gráfica y escritura indígena en la reducciones guaraníticas," in Saberes de la conversión: Jesuitas, indígenas e imperios coloniales en las fronteras de la cristiandad, ed. Guillermo Wilde (Buenos Aires: Editorial sB, 2011), 99-130; and Eduardo Neumann, Letra de índios: Cultura escrita, comunicação e memória indígena nas reduções do Paraguai (São Bernardo do Campo: Editorial Ñanduti, 2015). 
episodes. Nieremberg tells stories, many of which would have been familiar to his Spanish audience. The tales pertain to longstanding oral traditions with roots in the Middle Ages. For example, Nieremberg's tale of the deposed and naked king, which is depicted in plate 21 (see Figure 3), is similar to the one found in the fourteenth-century collection of moral lessons by Don Juan Manuel (1282-1348), El conde Lucanor (1330-35). ${ }^{50}$ By borrowing from popular culture and telling stories, Nieremberg essentially retells familiar parables and anecdotes according to the message of his treatise. Furthermore, their origin in oral forms of communication prior to the invention of the printing press is equally important to note. Both the vivid imagery of the subject matter and the captivating narrative style of the ascetical treatise therefore serve to explain how it came to be used for preaching and public readings in parishes and rural missions in Spain, as well as in the American missions.

\section{Conclusion: The Jesuit Network}

Scholarly literature has also traced the importance of the Jesuits' overseas activities regarding the exchange of knowledge between Europe and the mission territories in both Asia and the Americas. According to historian Steven Harris, "At its peak around 1750, the Society operated more than 500 colleges and universities in Europe, a hundred more in overseas colonies (mostly in Spanish America), and roughly 270 mission stations scattered around the globe."51 Because of the international character of the Jesuit order and the exchange of its members from one country to another, the Society was increasingly able to communicate with the mission outposts and to send resources from its headquarters located in Europe. Many of the missioners also returned to Europe with a wealth of knowledge and experience of the New World. The printing history of Nieremberg's treatise, together with the Jesuit methods of evangelization, should also be understood within this international context. On one hand, the Guaraní edition was both translated and printed due to the efforts of Spanish, Italian, and Austrian Jesuits with the help of the Guaraní craftsmen,

5o This tale is one of the moral "Exemplos" included in Don Juan Manuel's El conde Lucanor [1330-35], ed. Alfonso Sotelo (Mexico City: Red Editorial Iberoamericana, 1993), 286-89.

$5^{1}$ Steven J. Harris, "Jesuit Scientific Activity in the Overseas Missions, 1540-1773," Isis 96, no. 1 (2005): 71-79, here 72. For more on the Jesuit mission network, see Luis Millones Figueroa, "La intelligentsia jesuita y la naturaleza del Nuevo Mundo en el siglo XVII," in El saber de los jesuitas: Historias naturales y el Nuevo Mundo, ed. Luis Millones Figueroa and Domingo Ledezma (Frankfurt: Vervuert, 2005), 27-47. 


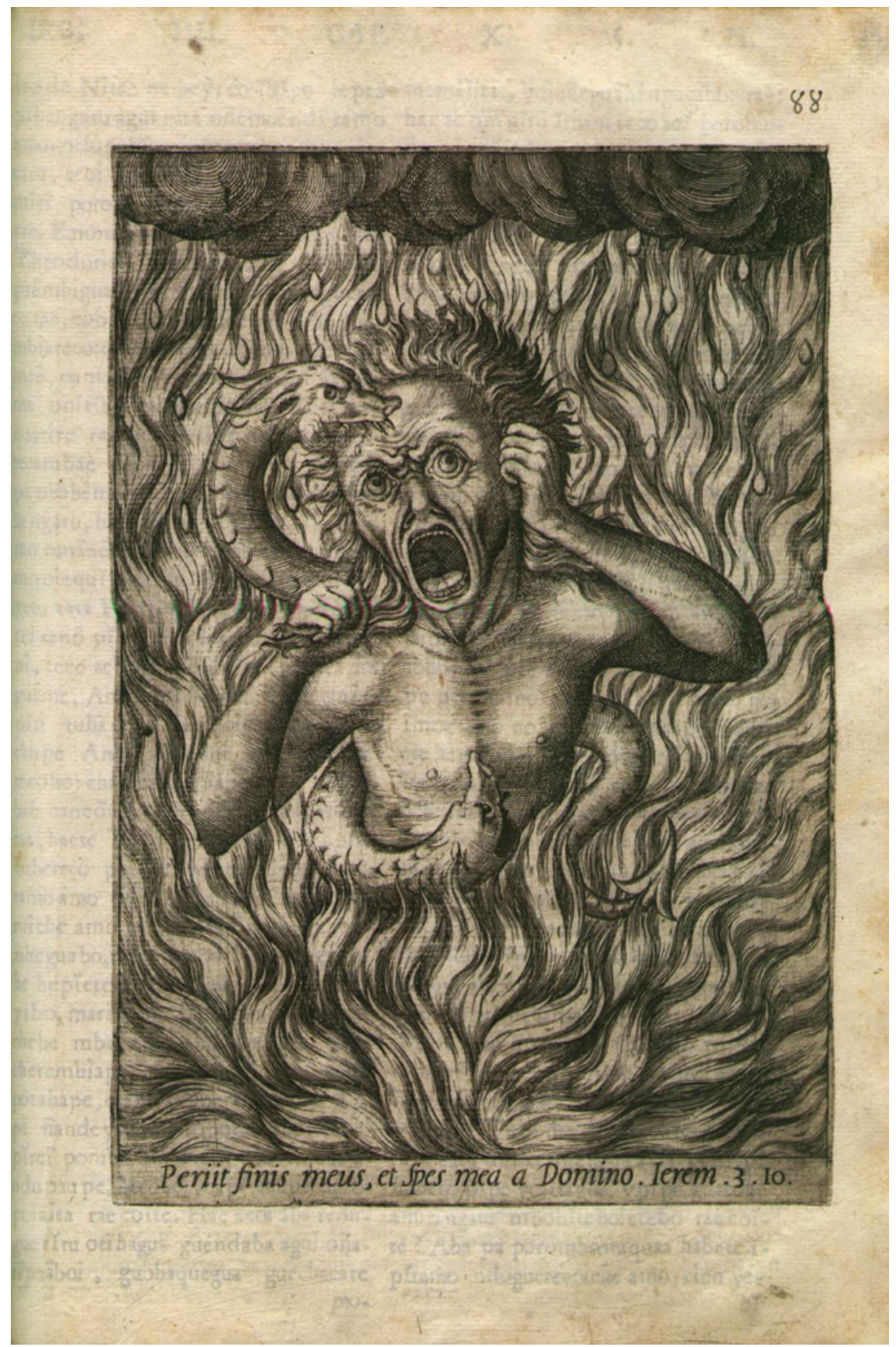

FIGURE 7 “Eternal Punishment” (Guaraní edition: Book 4, plate 88) 
such as Joan Yaparí. But on the other hand, the engravings also represent the use and exchange of illustrated materials from one mission to the next. This is most evident in the set of engravings depicting the torments of hell.

Nieremberg's extensive description of hell in Book 4 are equally evocative to his portrayal of human death. Admonishing sinners to repent and amend their lives, he instructs the reader to turn from vice to virtue, since sin will only lead to eternal suffering. The punishments of hell are explained in several graphic passages. While there are no engravings to accompany these exhortations in the Antwerp edition, the Guaraní translation includes eight plates depicting these torments. Seven of the illustrations depict scenes of a man suffering in hell, while one portrays a large image of a demon's head surrounded by snakes. Several individuals can be seen in the open mouth of the demon, as they are swallowed up in flames. Critical studies have noted how different these images are to the other plates designed by the Indians. The artists may either have created them or inserted already existing plates into the edition, but it is also possible that they were copied from other illustrated texts in the Jesuit library, since they are almost identical to a series of plates widely printed in Europe, Asia, and other places in Latin American. Similar plates can be found, for example, in various editions of ascetical treatises printed in the eighteenth century in Italy, England, Mexico, Peru, and the Philippines. ${ }^{52}$ While their inclusion in the Guaraní edition indicates the importance given to the visual apparatus and the communicative function of the text in connection to the author's exhortations, they also relate to the international scope of mission printing and the transmission of ascetical iconography.

The Guaraní edition of Nieremberg's famous treatise continues to be of interest to scholars for its curious hybrid illustrations created by the Guaraní

$5^{2}$ These eight engravings bear a striking resemblance to the plates printed in the Jesuit Giovanni Pietro Pinamonti's L'inferno aperto al cristiano [1688] (Milan, 1693), and in its English translation, Hell Opened to Christians (London, 1715). For more information on this treatise, see Sommervogel, "Jean Pierre Pinamonti," 6:763-92; and Elizabeth Boyd, "James Joyce's Hell-Fire Sermons," Modern Language Notes 75, no. 7 (1960): 561-71, here 563 . An almost identical set of these engravings also appears in Tagalog editions of Pinamonti's book, Ang Infiernong Nabubucsan, originally translated by the Jesuit Paul Klein (Clain), and printed in Manila in 1713; see José S. Arcilla, "Paul Klein (Clain)," in Diccionario histórico de la Compañía de Jesús, 3:2201-2; and "Paul Clain," in Sommervogel, 2:11971200. Guillermo Furlong notes the similarity of the eight Guaraní plates to a set created by the engraver Manuel Villavicencio in Puebla de los Angeles, Mexico, in the first half of the eighteenth century; Historia y bibliografía de la primeras imprentas rioplatenses, 1:329. Gil also notes the presence of the hell iconography in the mission territories of Peru and Brazil, "Introducción," liv-lvi. 
artisans. Not only are they emblematic of the ways in which the Jesuits developed the visual methods of evangelization, they reveal how certain elements of Christianity were adapted and indigenized by the Indians. The treatise transmitted important elements of the Catholic faith and doctrine from Spain to the New World, but also exemplifies how various media-printing, engraving, and preaching - were combined and incorporated into Jesuit catechetical methods. According to historian Bartomeu Meliá, the principal characteristic of the texts printed in the Paraguay mission was their communicative function. ${ }^{53}$ Like the music, painting, and sculptures produced in the reductions, the purpose of the literature was to communicate in multiple ways. In the words of Bouza, the Jesuits were able to evangelize most effectively because of this "poderosa combinación" (powerful combination) of the forms of communication they used. ${ }^{54}$ If it is possible to situate Nieremberg's ascetical text within the context of Catholic printing in Europe, it is also possible to understand its relevance to the mission work of the Jesuits in rural Spain and the Americas. But the course of its printing in Madrid and Antwerp, and then in the reductions of Paraguay, also indicates the global legacy of the ascetical treatise. By overcoming the barriers of time and space, Nieremberg's treatise would enable him to become the missionary he may have originally wanted to be.

53 Bartomeu Meliá, La lengua guaraní del Paraguay: Historia, sociedad y literatura (Madrid: Editorial Mapfre, 1992), 124-26.

54 Bouza, Papeles y opinión, 72. 